\title{
Assessment Level of Compliance with Public Procurement Act
}

\author{
Olusola Festus Akinradewo ${ }^{1}$, Omojola Anthony Bamidele ${ }^{2}$, and Deji Rufus Ogunsemi ${ }^{3}$ \\ ${ }^{1}$ Senior Lecturer, Department of Quantity Surveying, The Federal of Technology, Akure, Nigeria. E-mail: \\ foakinradewo@futa.edu.ng (corresponding author). \\ ${ }^{2}$ Deputy Director, Physical Planning and Development, National University Commission, Abuja, Nigeria. E-mail: \\ deomojola@mail.com \\ ${ }^{3}$ Professor, Department of Quantity Surveying, The Federal University of Technology, Akure, Nigeria. E-mail: \\ drogunsemi@futa.edu.ng
}

Project Management

Received February 25, 2021; revised December 21, 2021; accepted December 28, 2021

Available online February 12, 2022

\begin{abstract}
Public procurement is the acquisition of works, goods, and services by procuring entities using public funds. The study assesses the level of compliance with the public procurement act (PPA) 2007 in the north-central states of Nigeria. Questionnaires were administered to construction stakeholders in those seven (7) institutions that make up the northerncentral. A census survey was used to collect data from contractors, physical planning unit staff, consultants, and procurement administrative units that have executed Tertiary Institutions Fund (Tetfund) projects within 2012-2016. Data collected were analyzed using the relative importance index (RII), Kruskal Wallis, and Dunnett's test. The study revealed that all institutions have a good level of compliance with the tenet and component of the act for the procurement process. The study also shows that there is a significant difference in the level of compliance with the Act by Federal Universities. There was no significant difference in the level of compliance in University of Ilorin (Unillorin) and Federal University Lafia (UniLafia), University of Abuja (UniAbuja) and Federal University Lokoja (FULokoja), University of Jos (UniJos), and Federal University of Technology Minna (FUT Minna), Unillorin and FUT Minna, FULokoja and UniJos. The level of compliance of the National Open University of Nigeria (NOUN) is significantly different from other universities. The study indicated that the compliance level is very high, with an overall RII of $80.3 \%$ and $91.2 \%$ of respondents affirmation of the use of open competitive bidding, which represents fairness, accountability, and openness. The study also affirmed that understanding of tenets of the Act is very high in the study area. The study recommends that there should be a strong understanding between the stakeholders in the construction industry to increase the compliance rate of the PPA (2007) and enhance adequate monitoring of unethical behaviours.
\end{abstract}

Keywords: Accountability, compliance, procurement, procurement act, transparency.

Copyright (C) Journal of Engineering, Project, and Production Management (EPPM-Journal).

DOI 10.32738/JEPPM-2022-0012

\section{Introduction}

Procurement has always been one of the vital functions of governments all over the world. Public procurement comprises government purchasing, works, goods, and services resources for states activities, the basic purpose of which was to secure the best value for public money (Bodunrin, 2016). The public bodies are the largest purchasers that deal with a huge budget, and public procurement represents $13 \%$ of the world GDP (Ali, 2020), while Bosio and Djankov (2020) opined that it is a $12 \%$ estimate which may not cover military expenditure and healthcare sectors. The procurement budget of any nation like Nigeria is so high that it cannot be done shabbily, especially construction procurement, because of its vital role in infrastructure provision. The purpose of the PPA is for transparency, openness, equality, fairness, value for money, competitiveness, agreed standards, and time (Hui et al., 2011; Lex Mundi Publication, 2012; Krivish and Krekele, 2013; Adewole, 2014; Eze, 2015; WilliamsElegbe, 2015). Public procurement principles include nondiscrimination/fairness, use of electronic means, rules of origin, and offsets (Parra, 2021).

The successful procurement of construction projects is hindered by several factors, such as ineffective communication among construction parties, wrong choice of procurement methods, unethical practices of construction parties, skills inadequacy, bad bidding process, lack of cooperation between the procuring entity (client or project owner) and the contractor Crawshaw, 2017; Reading Report, 1995; Egan, 1998; Oyedele, 2016), and 
corruption (Obanikoro, 2013; Ibrahim and Mbamali, 2013; Transparency International, 2012). Lack of accountability in public procurement was so rampant in Nigeria before the advent of the Budget Monitoring and Price Intelligence Unit (BMPIU) under the presidency and was affecting the Nigerian budget. This was due to financial indiscipline and a lack of diligence in procurement.

Regrettably enough, Nigeria today can be described as a country of irony as the social-economic performance over the years remains superficial and unimpressive. This inclement experience was largely attributed to a high level of corruption or mismanagement of public resources closely linked up with the public sector procurement system that has brought untold hardship on the economic development and the citizens (Ekwekwuo, 2016). Before 2007, the way of awarding contracts was questionable because most ruling elites and friends were mostly awarded to become richer (Jacob, 2010). To reverse this irony of "poverty amid plenty," the government introduced the universal "best principle," the due process mechanism in the country's public procurement system was introduced in 2007. However, many questions, misconceptions, and criticism have trailed its implementation, which has made it increasingly difficult to secure maximum affection from the majority of Nigeria's populace.

Several studies have examined the procurement system and act in Nigeria. Musa et al. (2014) assessed the public procurement reforms in Nigeria. It was revealed that organizational culture, political interference, media publicity, planning, and others contribute negatively or positively to its implementation and compliance. Ojo and Gbadebo (2014) examined the non-compliance with procurement procedures in the procurement of works in Nigeria. It was shown that reasons for non-compliance are bid open/evaluation and reporting, procurement procedure, and a political party or authority influence of decisions. Nwafor (2013) also assessed the impact of the freedom of information act (FOIA) enacted in 2011 in public procurement in Nigeria about accountability and participation. Ogunsanmi (2013) evaluated the impact of procurement-related factors on construction performance. Enofe et al. (2015) evaluated the impact of PPA on government accountability and revealed that professionalism, transparency, and competition have a high impact on accountability, efficiency, and value for money. Muhammad et al. (2015) carried out an appraisal of construction project procurement policies in Nigeria; they opined that the success of the performance of public sector projects in Nigeria is tied to the impact of procurement strategy or policy used in providing the building.

The research questions are as follows; what is the level of compliance with the PPA (2007) for projects procured in the universities in the north-central states of Nigeria? What is the level of understanding of the act in universities in the North Central States of Nigeria? After a critical review of the literature review, it shows that there are no studies that have examined the level of compliance with PPA with specific reference to the university system in North Central. This study is significant because it will help us understand the implications of compiling to the procurement process mechanism in the aspect of funding and performance of the university system as a whole. This will provide useful information to stakeholders that manage funds in the university to ensure effective service delivery of projects. It will enhance the decisions of the stakeholders on the best procurement methods to be adopted for the project and in monitoring any unethical behaviour during the project's budget and implementation.

\section{Literature Review}

\subsection{Level of Compliance to the Provision of PPA (2007)}

It is pertinent to review the level of compliance to the provisions of relevant clauses of the procurement Act 2007 in Nigeria.

For openness, transparency, and accountability, all procurement must be advertised in at least two national dailies and the federal tender's journal for open competitive bidding or using the organization's websites. In compliance with Section 25(1-2) (I and II) of the PPA (2007), the procuring entities may either by way of national competitive bidding or international competitive bidding advertised. In case of goods and works under International competitive bidding, the invitation shall be carried out in at least two national newspapers and one relevant internationally recognized publication, and any official website of the procuring entities, and this must not be less than six (6) weeks before the deadline for submission. In case of goods and works valued under national competitive bidding, the advertisement shall be on the notice board of the procuring entity and any official website of the procuring entities, and this must not be less than six (6) weeks before the deadline for submission.

The Bureau of Public Procurement always came up with a regular review in the form of advertisement notices to MDAs requesting them of strict compliance with guidelines to avoid delays or non-publication of their advertisement in the Federal Tenders Journals and other relevant national newspapers (Federal Tenders Journal June 25, 2018).

All procuring entities shall expressly state the eligibility criteria that were required to suites the proposed procurement to be carried out. All conditions for the competitive selection will be stated for bidders to ascertain their competency for such a bid. Bidders that meet all the stated criteria are pre-qualified to move to the financial bidding.

Bidders whose tender fulfils the minimum eligibility requirement will always be invited for further participation in the proposed procurement. Instruction is usually given as to the number of bids a tenderer is entitled to for smooth control and management.

All bid documents are to be submitted in a specified location stated by the procurement entities giving specific addresses and locations. The date for closing of bid and time shall be specified in the advertisement. Any defaulter shall be rejected.

All tenderer or their representative shall be in attendance at the bids opening day for record purposes with an attendance taken by the secretary or a nominated agent of the procuring entities. Two credible observers must be invited by the procuring entity for every procurement process. One person each represents one organization.

Every loser in a bid must be informed on what made the bid not to be accepted by the procuring entity. This will reduce the time to be wasted in litigation.

The law mandated the procuring entity to prepare their needs in a prioritized manner stating the importance, justification before embarking on the procurement process. 
There should be an efficient procurement plan driven by need and assessment by the end-user, to ensure that goods and services needed are procured with due attention to economy and efficiency, and to ensure that public fund is used to buy only those goods and services needed for educational development. All this shall be carried out by the procurement planning committee of the procuring entities. All procurement must be budgeted for and adequate provision is made for payment.

All bids submitted and received shall be first be examined to determine if: they meet the minimum eligibility requirement stipulated in the bidding documents have been duly signed; they are substantially responsive to the bidding document are generally, otherwise, in order: they should meet the minimum eligibility requirement stipulated in the bidding documents are substantially responsive to the bidding document and are generally, otherwise, in order.

All bids shall be thoroughly analyzed by a committee or by the consultant employed by the procuring entity with the report submitted to the procuring entity tenders board for final approval.

After the completion of the due diligence by the procuring entity, the meeting of the university tenders board committee of the council will be called with the Vicechancellor or the head of the Institution as the secretary. The Tender Board Committee of the University governing board will then ratify and approve the award with an extract of the council to serve as the authority for award. Section 22 (1) of the Act stipulates that the procurement entity shall establish a tender board.

After carrying out due diligence on the tenders with the tender board committee of the university governing council, the letter of award will be issued to the successful bidders, and the process of mobilization and execution of the project begins.

The open competitive bidding principles based on equal treatment, transparency, and competition are expressly stated in law as fundamental principles for the conduct of procurement procedures. The law stipulates that the procurement entity is to be governed by principles of honesty, accountability, transparency, fairness, and equity. The overall objective of the public procurement law is to provide value for money by ensuring that funds are spent in a transparent, efficient, and fair manner.

[Section 161(b)] "Certificate of no objection" is defined in the law as:

"The document evidencing and authenticating that due process and the letters to the Law have been followed in the conduct of a procurement proceeding and allowing for the procuring entity to enter into contract or effect payments to contractors or suppliers from the treasury."

It is obvious that this certificate is the heart and soul of procurement then such a fundamental document should have had a time frame for its issuance from the time of its application. So that it would not give too much discretionary power to the public procurement officers of the bureau.

Before the passing into law of the PPA (2007), the public procurement system in Nigeria has been grossly abused leading to huge losses of resources. In a bid to sanitize the system, the federal government set up a due process unit under the presidency to undertake the reform (BMPIU, 2005). Due process is defined as a mechanism for ensuring strict compliance with openness, competition, and cost accuracy rules and procedures that should guide contract award (BMPIU, 2005). According to Ezekwesili (2004 in Ayangade et al. 2009). Due process is geared towards infusing the needed fiscal discipline and sound economic principles to ensure transparency, accountability, and rebuild public trust in governance by attacking the much-abused processes of the past. To adapt strictly with this assertion much has to be understood on the 2007 PPA which is not limited to understanding the procurement planning, the procurement procedure, awards, and the execution of projects.

\subsection{Awareness and Compliance of PPA (2007) in the Execution of Construction Projects in Nigeria}

To avoid the gap created by the traditional methods, a due process mechanism was introduced. Ayangade et al. (2009) carried out a study on the awareness of the implementation of the 2007 PPAs and their performance since their introduction. The study was carried out with a questionnaire and interview on the construction practitioners using both descriptive and inferential statistics. The study showed that the act has become a new initiative in the award of public procurement and was widely accepted by practitioners in the Nigerian system. The study revealed that with the act several savings has been recorded in the use of public fund by corrupt practices that usually characterized award of contracts. The study also showed that the absence of legal and other institutional frameworks was among the factors that inhibit the performance of the PPA (2007).

\section{Research Methodology}

The research was designed to examine the level of compliance with the acts on construction projects within the study area and this was pursued through a survey method. The questionnaire was used in collecting data. The reason for using a survey method approach is that the targeted population is within the physical planning unit, the contractors, the consultants, and the university procurement administrative unit. A census survey was employed for the seven (7) universities identified in northern-central Nigeria. These include the Unillorin, UniJos, UniAbuja, FUT Minna, UniLafia, FULokoja, and the NOUN, Abuja. The population includes stakeholders that were involved in the execution of TetFund completed projects in federal universities, within the north-central geo-political zone in Nigeria for five years i.e., 2012 - 2016. This period falls within the period of implementation of the Academic Staff Union of University (ASUU) agreement with the federal government of Nigeria. The construction stakeholders include contractors, consultants, the director of physical planning, and the director of procurement.

The study was through a well-structured questionnaire that was administered by hand and personal interview with the directors of physical planning and developments. The questionnaire was in three sections, the first section was on the background information of the respondents and it was an open question with options. The second section was on the level of compliance with the tenet of the Act and the questions were on a 5-point Likert scale with 5 being the highest. The interview questions were open questions and options of yes or no; positive or negative or appropriate options were provided for the respondents. The interview questions were administered to directors of physical 
planning units of seven universities. The survey questionnaires were administered to the respondents with the help of the director of physical planning and the director of procurement based on the interface they have with the other relevant stakeholders. On the other hand, the researcher carried out a personal interview with the construction stakeholders and the contractors. The questionnaire consisted of various sections for practitioners to express their in-depth understanding of the 2007 PPA, and the interview was to measure the relationship between the compliance and project performance index. Validity of the instrument was ensured through pilot surveys carried out by the researcher as recommended by Trochim (2002). The validity of the response was based on the fact that the respondents were directly involved in the execution of the projects used as the population for the study. This study is based on compliance theory. According to Cherry (2021), compliance theory involves changing your behaviour in some way because someone else requested you to do so. While you may have had the option to refuse the request, you chose to comply. Compliance is different from obedience in which the other individual is in a position of authority. Compliance does not rely upon being in a position of power. For example, the case of how sellers can influence buyers and persuade them to purchase goods and services.

The analytical tools used for this study vary from RII, Kruskal-Wallis H, Dunnett's test, and RII in \%. The decision rue is that RII $\geq 70 \%$ is regarded as "high compliance" while RII $<70 \%$ is "low compliance" KruskalWallis H-test was conducted to measure the difference in perception (ranking) of respondents on the level of compliance to the 2007 PPA in universities in the North Central States of Nigeria. Mean item score is used for ranking and determining of significance importance of field-collected data. The highest mean item score "MIS" was ranked first and other in such subsequent descending order. Dunnett's test was used to test where the difference in the opinions lies.

\section{Findings and Discussions}

Table 1 shows the number of projects, contractors, and consultants for each university. The total number of projects for the seven (7) universities is 110. Also, the number of contractors engaged in those projects is 94 , and the numbers of consultants involved in these projects are 178. In Table 3, the number of questionnaires distributed was 286 , where 165 questionnaires were retrieved. This gave a percentage of $57.69 \%$ while $42.31 \%$ was withheld by some respondents. For each Institution, the number and percentage of retrieved questionnaires are shown below.

In Table 2, the director of physical planning and development of each university was selected to be part of the population. Also, the director of procurement for the seven (7) universities was part of the population. The directors were the ones that were contacted and gave the comprehensive list of all stakeholders that were engaged in those projects i.e., consultants and contractors. The total stakeholders involved in these projects were 286.

Fig. 1 displays the professions of respondents' which includes the town planners, procurement officers, architects, and so on. The majority of the respondents were quantity surveyors and architects representing $26.1 \%$ and $24.8 \%$ respectively of the total population of those who responded. The next professions that followed the architects are engineers making up $20.0 \%$ and builders with $15.8 \%$. The other professions represented include procurement officers $10.9 \%$ and town planners representing $2.4 \%$.

Table 1. Number of projects, contractors, and consultants of institutions

\begin{tabular}{ccccc}
\hline S/N & University & $\begin{array}{c}\text { Numbers of } \\
\text { projects }\end{array}$ & $\begin{array}{c}\text { Numbers of } \\
\text { contractors }\end{array}$ & $\begin{array}{c}\text { Numbers of } \\
\text { consultants }\end{array}$ \\
\hline 1 & Unillorin & 24 & 23 & 96 \\
2 & UniJos & 27 & 22 & 18 \\
3 & UniAbuja, & 5 & 5 & 4 \\
4 & FUT Minna & 6 & 6 & 20 \\
5 & UniLafia & 11 & 9 & 27 \\
6 & FULokoja & 31 & 23 & 11 \\
7 & NOUN, Abuja & 6 & 6 & 2 \\
\hline & Total & 110 & 94 & 178 \\
\hline
\end{tabular}

Table 2. Number of stakeholders in institutions

\begin{tabular}{clc}
\hline S/N & \multicolumn{1}{c}{ Stakeholders } & Population \\
\hline 1. & Director of Physical Planning & 7 \\
2. & Director of Procurement & 7 \\
3. & Consultants to the institutions & 178 \\
4. & Contractors to the Institution & 94 \\
& Total Stakeholders & 286 \\
\hline
\end{tabular}

Table 3. Numbers of distributed, retrieved questionnaires and percentage of retrieved

\begin{tabular}{clccc}
\hline S/N & University & $\begin{array}{c}\text { Numbers } \\
\text { distributed }\end{array}$ & $\begin{array}{c}\text { Numbers } \\
\text { retrieved }\end{array}$ & $\%$ \\
\hline 1 & Unillorin & 121 & 53 & 43.80 \\
2 & UniJos & 42 & 26 & 61.90 \\
3 & UniAbuja & 11 & 10 & 90.91 \\
4 & FUT Minna & 28 & 17 & 60.71 \\
5 & UniLafia & 38 & 22 & 57.89 \\
6 & FULokoja & 6 & 29 & 80.56 \\
7 & NOUN, Abuja & 31 & 8 & 80.00 \\
\hline & Total & 110 & 165 & 57.69 \\
\hline
\end{tabular}

The role/duties performed by each respondent were shown in Fig. 2. The duties of the respondents are procurement officers, consultants, contractors, and directors of the physical planning unit. Those that are the director of physical planning are 19 respondents representing $11.5 \%$ while consultants represent $43.6 \%$ i.e., 72 respondents. $26.1 \%$ make up the contractors having 43 respondents and for procurement officers, we have 31 respondents connoting $18.8 \%$ of the total population.

In the same vein, $18.8 \%$ of the respondents were Higher National Diploma (HND) graduates, $13.9 \%$ of the total population were post graduate diploma (PGD), 37\% of all respondents were bachelor of science/bachelor of technology (B.Sc/B.Tech), and those with the master of science/ master of technology (M.Sc/M.Tech) were 30.3\%.

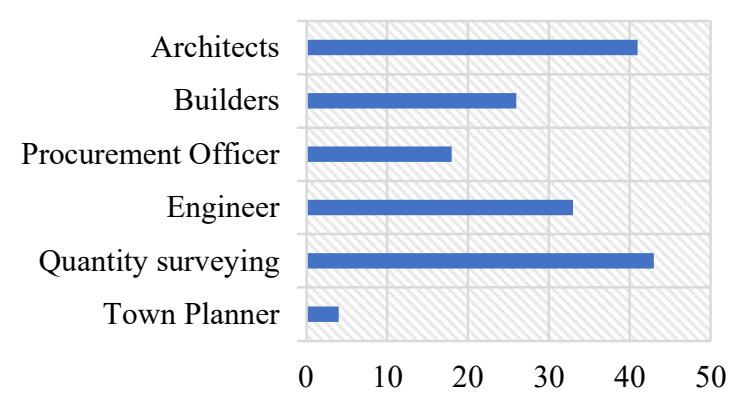

Fig. 1. Professions of respondents 


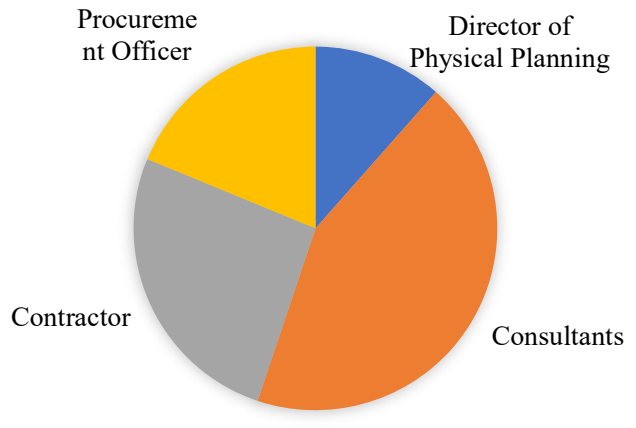

Fig. 2. Designation of respondents

Fig. 3 further revealed that those with 1-5 years of experience in the procurement process depict $18.8 \%$. Professionals with 6-10 years of experience connote $35.8 \%$ and those $11-15$ years denote $16.4 \%$. $13.9 \%$ of the total respondents represent those with 16-20 years of experience. Respondents over 20 years show $15.2 \%$ and this shows that $81.2 \%$ of the professionals had six years and above in the procurement process. It means that the level of experience and intellectual capacity of the respondents are high. This shows that the high level of experience will have a significant impact on their appreciation of the issues being discussed in this study. Thus, make them suitable to provide relevant information on the level of compliance with the PPA (2007) on construction projects performance by the universities in the North Central States of Nigeria.

Table 5 depicts the procurement system regularly used by various federal universities in the north-central. However, $91.2 \%$ of the respondents affirmed the usage of open competition, $4.8 \%$ each affirmed the selective and negotiated procurement system. These from the survey revealed that the tenant of the PPA (2007) was being followed.

Table 6 indicates a high level of compliance with the PPA 2007 in all the tenets and components of the acts with an overall RII of $80.3 \%$. Advertising of tenders, issuance of awards letter, bid submission and bid opening information, submission of the tender report, budgetary provisions before procurement process, analysis of tenders submitted by professionals, prequalification criteria stated and minimum tender documents required in order of compliance has an excellent compliance rate with an RII of $89.6 \%, 83.3 \%, 82.5 \%, 82.3 \%, 82.2 \%, 82.0 \%, 81.7 \%$, $81.5 \%$, and $80 \%$ respectively in all federal universities in the north-central of Nigeria. Similarly, meetings of the universities tenders board for ratification of awards, collection of no objection letter from BPP, transparency of the system by eliminating the interest of procurement officer, working within the stipulated time for prequalification and award, the establishment of the procurement planning committee, stated criteria for qualitative selective, attendance of bid opening by interested members of public and strict adherence to all the procurement procedures had a better compliance rate with an RII of over $75 \%$ i.e. $79.6 \%, 76.1 \%, 79.3 \%, 77.7 \%$, $79.6 \%, 79.3 \%, 77.6 \%$, and $79.1 \%$ respectively.
Table 4. Academic qualification of respondents

\begin{tabular}{lcc}
\hline Professional background & Frequency & Percentage \\
\hline HND & 31 & 18.8 \\
B.Sc/B.Tech Degree & 61 & 37.0 \\
PGD & 23 & 13.9 \\
M.Tech/M.Sc. Degree & 50 & 30.3 \\
Total & 165 & 100.0 \\
\hline
\end{tabular}

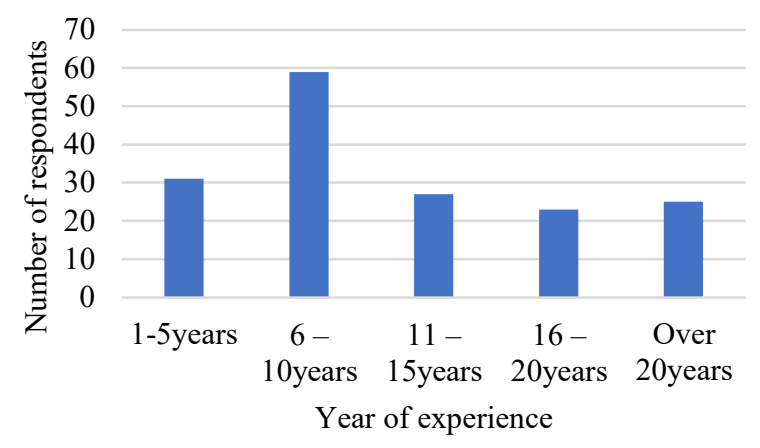

Fig. 3. Years of experience of respondents

Another tenet and component of the acts with a good compliance rate is the information of bidders giving reasons for disqualification with $73.0 \%$. For FULafia, FUTMinna, Unillorin, FULokoja, NOUN, UniAbuja, and UniJos the overall RII for all the variables under tenets and components of acts are $87.5 \%, 82.9 \%, 85.6 \%, 79.0 \%$, $71.2 \%, 75.7 \%$, and $79.9 \%$ respectively. Apart from NOUN where some of the tenets scored less than $70 \%$ RII, the majority of the universities scored more than the minimum $70 \%$ RII set decision rule earlier.

Table 7 shows that there is a statistical reason to reject the null hypothesis since the significant probability 0.004 and chi-square value of 66.999 with 6 degrees of freedom less than the alpha level 0.05 . It can therefore be concluded that there is a significant difference in the level of compliance with the 2007 procurement act by federal universities in North-Central Nigeria.

The table further revealed that FULafia has the highest compliance rate with a mean ranking of 95.59 closely followed by the UniIlorin with 89.12. While the NOUN had the least compliance rate of 19.41 . However, the post hoc analysis in Table 8 further shows the level of significant difference in the level of compliance with the 2007 procurement act in various institutions.

Table 8 shows that there is no significant difference in the level of compliance in Unillorin and FULafia, UniAbuja and FULokoja, UniJos and FUT Minna, Unillorin and FUT Minna, as well as Lokoja and UniJos since the significant probability in all cases are greater than 0.05 level of significance. While the level of compliance of the NOUN is significantly different from other Universities. 
Table 5. Procurement system regularly used by Institution

\begin{tabular}{ccccccccc}
\hline $\begin{array}{c}\text { Procurement } \\
\text { System }\end{array}$ & UniIlorin & UniJos & UniAbuja & FULokoja & FUTMinna & NOUN & FULafia & Total \\
\hline Open Competitive & 48 & 26 & 10 & 27 & 13 & 5 & 20 & 149 \\
$\%$ & 29.09 & 15.76 & 6.06 & 16.36 & 7.87 & 3.03 & 12.12 & 90.30 \\
Selective & 2 & 0 & 0 & 2 & 2 & 0 & 2 & 8 \\
$\%$ & 1.21 & 0 & 0 & 1.21 & 1.21 & 0 & 1.21 & 4.85 \\
Negotiated & 3 & 0 & 0 & 0 & 2 & 3 & 0 & 8 \\
$\%$ & 1.82 & 0 & 0 & 0 & 1.21 & 1.82 & 0 & 4.85 \\
Total (\%) & $53(32.1)$ & $26(15.8)$ & $10(6.1)$ & $29(17.6)$ & $17(11.1)$ & $8(4.8)$ & $22(13.3)$ & $156(100 \%)$ \\
\hline
\end{tabular}

NB: Percentages are enclosed in parenthesis

Table 6. Level of compliance with the PPA (2007) by institutions

\begin{tabular}{|c|c|c|c|c|c|c|c|c|}
\hline \multirow{2}{*}{$\begin{array}{c}\text { Tenet and component of } \\
\text { the acts }\end{array}$} & \multicolumn{8}{|c|}{ Institutions (RII \%) } \\
\hline & FULafia & FUTMinna & Unillorin & UniLokoja & NOUN & UniAbuja & UniJos & Pooled \\
\hline Advertising of tenders & 98.2 & 97.6 & 96.6 & 89.0 & 75.0 & 82.0 & 88.8 & 89.6 \\
\hline $\begin{array}{l}\text { Prequalification criteria } \\
\text { stated }\end{array}$ & 79.1 & 88.2 & 86.5 & 80.0 & 72.5 & 77.8 & 86.2 & 81.5 \\
\hline $\begin{array}{l}\text { Stated criteria for } \\
\text { qualitative selective }\end{array}$ & 85.5 & 77.6 & 88.8 & 80.0 & 67.5 & 74.0 & 81.6 & 79.3 \\
\hline $\begin{array}{l}\text { Minimum tender } \\
\text { documents required }\end{array}$ & 82.7 & 81.2 & 83.8 & 81.4 & 67.5 & 82.2 & 81.5 & 80.0 \\
\hline $\begin{array}{l}\text { Bid submission and bid } \\
\text { opening information }\end{array}$ & 86.4 & 85.9 & 87.5 & 76.6 & 77.5 & 77.8 & 86.2 & 82.5 \\
\hline $\begin{array}{l}\text { Attendance of bid opening } \\
\text { by interested members of } \\
\text { the public }\end{array}$ & 84.5 & 83.5 & 81.2 & 77.9 & 65.0 & 74.0 & 76.9 & 77.6 \\
\hline $\begin{array}{l}\text { Information of bidders } \\
\text { giving reasons for } \\
\text { disqualification }\end{array}$ & 83.6 & 74.1 & 78.5 & 72.9 & 67.5 & 70.0 & 64.6 & 73.0 \\
\hline $\begin{array}{l}\text { Budgetary provisions } \\
\text { before procurement } \\
\text { process }\end{array}$ & 92.7 & 81.2 & 81.9 & 80.0 & 80.0 & 80.0 & 78.5 & 82.0 \\
\hline $\begin{array}{l}\text { Analysis of tenders } \\
\text { submitted by professionals }\end{array}$ & 84.5 & 87.1 & 88.3 & 76.9 & 72.5 & 77.8 & 84.6 & 81.7 \\
\hline $\begin{array}{l}\text { Submission of tender } \\
\text { report }\end{array}$ & 92.7 & 82.4 & 86.9 & 80.0 & 75.0 & 75.0 & 83.3 & 82.2 \\
\hline $\begin{array}{l}\text { Meetings of the } \\
\text { universities tenders board } \\
\text { for ratification of awards }\end{array}$ & 84.5 & 78.8 & 85.5 & 80.7 & 65.0 & 76.0 & 86.9 & 79.6 \\
\hline Issuance of awards letter & 90.0 & 81.2 & 88.2 & 80.0 & 77.5 & 76.0 & 90.4 & 83.3 \\
\hline $\begin{array}{l}\text { Collection of no objection } \\
\text { letter from BPP }\end{array}$ & 87.3 & 77.6 & 80.4 & 80.8 & 55.0 & 75.0 & 76.8 & 76.1 \\
\hline $\begin{array}{l}\text { Strict adherence to all the } \\
\text { procurement procedures }\end{array}$ & 84.5 & 84.0 & 86.3 & 73.6 & 77.5 & 74.0 & 73.8 & 79.1 \\
\hline $\begin{array}{l}\text { Transparency of the } \\
\text { system by eliminating the } \\
\text { interest of procurement } \\
\text { officer }\end{array}$ & 90.9 & 83.5 & 85.8 & 78.6 & 72.5 & 74.0 & 70.0 & 79.3 \\
\hline $\begin{array}{l}\text { Working within the } \\
\text { stipulated time for } \\
\text { prequalification and award }\end{array}$ & 86.4 & 81.2 & 83.4 & 78.3 & 67.5 & 74.0 & 73.1 & 77.7 \\
\hline $\begin{array}{l}\text { Establishment of the } \\
\text { procurement planning } \\
\text { committee }\end{array}$ & 93.6 & 83.5 & 86.2 & 76.4 & 75.0 & 68.0 & 74.6 & 79.6 \\
\hline Overall & 87.5 & 82.9 & 85.6 & 79.0 & 71.2 & 75.7 & 79.9 & 80.3 \\
\hline
\end{tabular}

However, the RII in Table 6 further indicates the level of compliance to each tenet and component of the PPA (2007). NOUN falls into group one with the least level of compliance, while UniAbuja and FULokoja, fall in group two. UniJos was significantly higher than FULokoja and fell in group three. FUT Minna, Unillorin, and FULafia had the greatest level of compliance and this falls into groups four, five, and six, respectively. 
To supplement stakeholders' opinion on the implementation of the PPA (2007), an interview was conducted with the result as presented in Table 9. The table shows that $57.1 \%$ of the Institution affirmed that every project always goes through advertisement even if it is more than or within the institutional board or management approval, $28.6 \%$ said that any project above 500 million must be approved by the Federal Ministry of Education Board while 14.3\% claimed that the Federal Executives Council (FEC) often handle all relevant procedures and forward the recommendation to the appropriate question.

Table 7. Kruskal Wallis test on the institutional level of compliance with the PPA (2007)

\begin{tabular}{lccccc}
\hline $\begin{array}{c}\text { The Institution } \\
\text { (Grouping } \\
\text { Variable) }\end{array}$ & $\begin{array}{c}\text { Mean } \\
\text { Rank }\end{array}$ & Ranking $\begin{array}{c}\text { Chi- } \\
\text { Square }\end{array}$ & Df $\begin{array}{c}\text { Asymp. } \\
\text { Sig. }\end{array}$ \\
\hline FULafia & 95.59 & 1 & 66.999 & 6 & 0.004 \\
Unillorin & 89.12 & 2 & & & \\
FUTMinna & 72.44 & 3 & & & \\
UniJos & 58.97 & 4 & & & \\
FULokoja & 50.56 & 5 & & & \\
UniAbuja & 33.91 & 6 & & & \\
NOUN & 19.41 & 7 & & & \\
\hline
\end{tabular}

Table 8. Duncan post hoc test on the institutional level of compliance with the PPA (2007)

\begin{tabular}{|c|c|c|c|c|c|c|}
\hline \multirow{3}{*}{ Institutions } & \multicolumn{6}{|c|}{ Subset for alpha $=0.05$} \\
\hline & Group & Group & Group & Group & Group & Group \\
\hline & 1 & 2 & 3 & 4 & 5 & 6 \\
\hline NOUN & 3.5588 & & & & & \\
\hline UniAbuja & & 3.7869 & & & & \\
\hline FULokoja & & 3.9500 & 3.9500 & & & \\
\hline UniJos & & & 3.9937 & 3.9937 & & \\
\hline FUTMinna & & & & 4.1430 & 4.1430 & \\
\hline UniIlorin & & & & & 4.2815 & 4.2815 \\
\hline FULafia & & & & & & 4.3743 \\
\hline Sig. & 1.000 & .067 & .621 & .093 & .119 & .295 \\
\hline
\end{tabular}

In the same vein, $71.4 \%$ of the Institutions had projects that went for external approval in the last five years (20122016). These projects were the Centre of Excellence building donated by the Central Bank of Nigeria located in the UniJos, Faculty of Law building in the UniAbuja, and UniLafia take-off grants projects while Unillorin and FULokoja had no projects that went for external approval. The table further reveals that it takes an average of a month for the release of the no objection letter from the Bureau of Public procurements. The table also shows that at Unillorin, it takes 40 days, and three weeks at the UniJos while it is not common in FULokoja. Table 9 shows that $85.7 \%$ of the respondents interviewed indicated that it takes an average of 3 weeks for the approval in principle for TetFund projects which largely depends on the volume of the projects while only $14.3 \%$ affirmed to 7 weeks of approval. The table also shows that $71.4 \%$ of the Directorate of Public Procurement (DPP) interviewed indicated that it takes an average of 8 weeks for public procurement procedure to complete in their university from the period of advertisement to award while equal number $14.3 \%$ affirmed to 6 and 10 weeks respectively. It could be seen from this analysis that it takes an average of 8 weeks for the completion of the procurement process. In the same vein, the table identifies advertisement or submission of proposals which is one of the tenets of the PPA (2007) as the major ways of sourcing for project consultants in a federal university in North Central. This analysis implies that all the institutions complied with this component of the act which further justified the analysis on the level of compliance in Table 9. The table shows that $85.7 \%$ of the Institution had no interference from the regulatory Authorities like TetFund, National University Commission (NUC), FME, and the university management on the selection of contractors for a project. While 14.3\% (UniLokoja) indicated at times. Similarly, the majority of the universities said that any contractor that is dissatisfied with the selection process will petition to BPP Independent Corrupt Practices Commission (ICPC) or Economic and Financial Crime Commission (EFCC) as well as given reasons for such contractors disqualification for such an award by the Institution if demanded. Table 9 indicates that $71.4 \%$ of the Institution had no suspended delayed or readvertised project while $28.6 \%$ had their project suspended delayed because of some politically motivated individuals that are involved in such project. The table also shows that $85.7 \%$ of the Institution affirmed that the implementation of the 2007 PPA had a positive influence on project delivery and $14.3 \%$ (Unillorin) affirmed to negative impact which is attributed to long procedures if the lowest best response considered affecting the quality of the project. Similarly, the majority of the DPP did not understand the function of the national council of procurement act which they attributed to, not in place of the council or noninauguration.

The general overview of the level of compliance with the PPA (2007) was higher going by the result from the fieldwork with an RII of $80.3 \%$. This assertion was corroborated by Musa et al. (2014) in their study of public procurement reform in Nigeria: Implementation and Compliance Challenges where it was revealed that the awareness of the act was on the increase within the MDAs by the establishment of the procurement planning committee and procurement departments like we have in all the Universities studied by the research. The study further revealed that an open and competitive method of procurement was adopted which works in line with the objective of the PPA (2007). This also aligns with Enofe et al. (2015) who assessed the impact of the PPA on government accountability and revealed that transparency and open competition has a high positive impact on government accountability. This was against Hui et al. (2011) who affirmed that lack of open competition leads to corruption, time, and cost overruns of projects. This means that open competition enhances transparency, openness, value for money, and better accountability.

Ayangade et al. (2009) investigated the performance of Due process Mechanism in the execution of a Construction Project in Nigeria. Their study covered both the private and public sectors of the economy which revealed that Due process for award of contracts in Nigeria is becoming a new initiative that is widely embraced by every sector for fairness, accountability and this has impacted positively in public fund saving that would have been corrupted away.

The study further enumerated that inadequacy of legal framework and other institutional support to discipline erring officers is a major impediment for the success of the PPA (2007). Familoye (2012) agreed with the study that the 
level of awareness of the PPA (2007) is high but more needs to be done in the area of capacity training of the practitioners, increasing the procurement awareness, professionalizing the procurement cadre in the system, and agree that PPA (2007) is an adequate procurement instrument to be used in the country.

Osei-Tutu et al. (2011) in their study on the level of compliance with the PPA (Act 663) in Ghana and the findings disagree with the study carried out in the universities in the North Central State of Nigeria where the level of awareness is low in Ghana and the universities in the North Central States of Nigeria is high. Also, Hui et al. (2011) affirmed that there are issues in analyzing procurement where procurement officers are blamed for malpractice and non-compliance to procurement policies and procedures.
Compliance with the Act is higher but all the results of various studies in Nigeria must be given attention by the government to improve the transparency of projects. Ojo and Gbadebo (2014) opined that the reasons for noncompliance are bid open/evaluation and reporting, procurement procedure and political party which is not consistent with bid submission and bid opening information, submission of tender, and strict adherence to all procurement procedures which has an excellent and better rate. The award of contract in the study shows that there is excellent compliance with the procurement act which is not in alignment with Jacob (2010) who postulated that most government contracts are awarded to friends and cronies to gather wealth for themselves. This implies the university system complies with the rule of PPA 2007 in the award of a contract to any contractor that bids.

Table 9. Institutional means of handling projects outside the limit approval

\begin{tabular}{|c|c|c|c|c|c|c|c|c|c|}
\hline \multirow{2}{*}{ Variables } & \multirow{2}{*}{ Responses } & \multicolumn{7}{|c|}{ Institutional Frequency } & \multirow{2}{*}{ Total } \\
\hline & & FULafia & UniIlorin & FUTMinna & UniJos & FULokoja & UniAbuja & NOUN & \\
\hline \multirow{3}{*}{$\begin{array}{l}\text { Means of handling } \\
\text { projects outside the } \\
\text { limit approval }\end{array}$} & Advertisement & $\checkmark$ & $\checkmark$ & $\checkmark$ & & & & & $4(57.1)$ \\
\hline & $\begin{array}{l}\text { Ministerial } \\
\text { Board (FME) }\end{array}$ & & & & $\checkmark$ & $\checkmark$ & & & $2(28.6)$ \\
\hline & FEC & & & & & & $\checkmark$ & & $1(14.3)$ \\
\hline \multirow{2}{*}{$\begin{array}{l}\text { Projects that went } \\
\text { for external } \\
\text { approval in the last } \\
\text { five years }\end{array}$} & Yes & $\checkmark$ & & $\checkmark$ & $\checkmark$ & & $\checkmark$ & $\checkmark$ & $5(71.4)$ \\
\hline & No & & $\checkmark$ & & & $\checkmark$ & & & $2(28.6)$ \\
\hline \multirow{4}{*}{$\begin{array}{l}\text { No of days take for } \\
\text { the release of letter } \\
\text { of no objection } \\
\text { from the bureau of } \\
\text { public }\end{array}$} & 1 month & $\checkmark$ & & $\checkmark$ & & & $\checkmark$ & $\checkmark$ & $4(57.1)$ \\
\hline & Seven weeks & & & & $\checkmark$ & & & & $1(14.3)$ \\
\hline & Not common & & & & & $\checkmark$ & & & $1(14.3)$ \\
\hline & $\begin{array}{l}1 \text { month \& } 2 \\
\text { weeks }\end{array}$ & & $\checkmark$ & & & & & & $1(14.3)$ \\
\hline \multirow{2}{*}{$\begin{array}{l}\text { Days for approval } \\
\text { in principle for } \\
\text { TetFund release }\end{array}$} & 3 weeks & & $\checkmark$ & $\checkmark$ & $\checkmark$ & $\checkmark$ & $\checkmark$ & $\checkmark$ & $6(85.7)$ \\
\hline & 7 weeks & $\checkmark$ & & & & & & & $1(14.3)$ \\
\hline \multirow{3}{*}{$\begin{array}{l}\text { Days for public } \\
\text { procurement } \\
\text { procedure }\end{array}$} & 6 weeks & $\checkmark$ & & & & & & & $1(14.3)$ \\
\hline & 8 weeks & & $\checkmark$ & $\checkmark$ & & $\checkmark$ & $\checkmark$ & $\checkmark$ & $5(71.4)$ \\
\hline & 10 weeks & & & & $\checkmark$ & & & & $1(14.3)$ \\
\hline $\begin{array}{l}\text { Ways of sourcing } \\
\text { for project } \\
\text { consultants }\end{array}$ & $\begin{array}{l}\text { Advertisement } \\
\text { or proposal }\end{array}$ & $\checkmark$ & $\checkmark$ & $\checkmark$ & $\checkmark$ & $\checkmark$ & $\checkmark$ & $\checkmark$ & $7(100)$ \\
\hline \multirow{2}{*}{$\begin{array}{l}\text { Interference from } \\
\text { the regulatory } \\
\text { authorities }\end{array}$} & $\begin{array}{l}\text { No } \\
\text { interference }\end{array}$ & $\checkmark$ & $\checkmark$ & $\checkmark$ & $\checkmark$ & & $\checkmark$ & $\checkmark$ & $6(85.7)$ \\
\hline & $\begin{array}{l}\text { Interference at } \\
\text { times }\end{array}$ & & & & & $\checkmark$ & & & $1(14.3)$ \\
\hline \multirow{2}{*}{$\begin{array}{l}\text { Step taken when a } \\
\text { contractor is } \\
\text { dissatisfied with } \\
\text { the selection } \\
\text { process }\end{array}$} & $\begin{array}{l}\text { Petition to } \\
\text { BPP or High } \\
\text { Court, EFCC } \\
\text { and ICPC } \\
\end{array}$ & $\checkmark$ & $\checkmark$ & $\checkmark$ & & $\checkmark$ & & $\checkmark$ & $5(71.4)$ \\
\hline & $\begin{array}{l}\text { Reasons were } \\
\text { given to such } \\
\text { contractor }\end{array}$ & & & & $\checkmark$ & & $\checkmark$ & & $2(28.6)$ \\
\hline \multirow{2}{*}{$\begin{array}{l}\text { Project suspended } \\
\text { delayed or re- } \\
\text { advertised }\end{array}$} & Yes & & $\checkmark$ & & & $\checkmark$ & & & $2(28.6)$ \\
\hline & No & $\checkmark$ & & $\checkmark$ & $\checkmark$ & & $\checkmark$ & $\checkmark$ & $5(71.4)$ \\
\hline \multirow{2}{*}{$\begin{array}{l}\text { Impact of the } \\
\text { implementation of } \\
\text { PPA } 2007 \text { on } \\
\text { project delivery }\end{array}$} & Negative & & $\checkmark$ & & & & & & $1(14.3)$ \\
\hline & Positive & $\checkmark$ & & $\checkmark$ & $\checkmark$ & $\checkmark$ & $\checkmark$ & $\checkmark$ & $6(85.7)$ \\
\hline $\begin{array}{l}\text { Understanding the } \\
\text { function of the } \\
\text { national council of } \\
\text { public procurement }\end{array}$ & No & $\checkmark$ & $\checkmark$ & $\checkmark$ & $\checkmark$ & $\checkmark$ & $\checkmark$ & $\checkmark$ & $7(100)$ \\
\hline
\end{tabular}


The study further confirmed that advertisement of tenders, prequalification criteria, qualitative selection, minimum tender documents required, bid submission and bid opening information, attendance at bid openings by interested members of the public, information of bidders giving reasons of disqualification, budgetary provision before procurement process and analysis of tenders submitted by professionals are critical factors for the compliance which the study came up with. The study confirms the conclusion of Familoye (2015) that effort should be made to surmount the significant challenges by all stakeholders concerned with the implementation of the PPA (2007), and the study also showed that size and complexity of public procurement, political interference, by the executives and shortage of public procurement practitioners are inimical to the success of the Act.

The study showed that the most important benchmarks both in the level of importance and the level of compliance are advertisement of tenders, submission of the tender report, meetings of the universities tenders board for ratification of awards, issuance of award letters, strict adherence to all the procurement procedures, transparency of the system by eliminating the interest of procurement officers, working with the stipulated time for prequalification and award and establishment of procurement planning committee all this are the tenet of the PPA (2007) to ensure that enhance the trust of the bidders to ascertained that transparency, probity, fairness, and rules of engagement were followed in the process of procurement in the universities in the North Central States of Nigeria. The study further confirmed the conclusion of Adusei and Dadson (2015) that public procurement is inherently a politically sensitive activity, not just because it involves significant amounts of public funds by its magnitude but it demands high-quality public governance in terms of transparency and accountability as well as effective management that can deliver an optimum risk management and value for money.

\section{Conclusion and Recommendation}

The study has been able to reveal the level of compliance with the PPA of 2007. The highest level of compliance for the tenet and component of the acts for all the federal universities in the advertising of tenders with $89.6 \%$. The lowest level of compliance level is the information of bidders giving reasons for disqualification with $73.0 \%$. Also, from the perspective of each Institution, the Institution with the lowest compliance level in the factors for tenet and component of the acts is NOUN having $87.5 \%$ while the highest compliance level is FULafia with $71.2 \%$. This means there is a good compliance level with the PPA 2007 by the universities. Besides, Kruskal Wallis was used to finding the difference in the opinions of stakeholders in different universities. It was revealed that there is a significant difference in the level of compliance with the 2007 procurement act by federal universities because the $p$ value was less than 0.05 .

By using Dunnett's test, it aids to reveal where the significant difference lies. There was no significant difference in the level of compliance in Unillorin and FULafia, UniAbuja and FULokoja, UniJos and FUT Minna, Unillorin and FUT Minna, Lokoja, and UniJos since it is greater than 0.05 . The level of compliance of NOUN is significantly different from other universities. The study discovered that the compliance level is very high with an overall RII of $80.3 \%$ and with $91.2 \%$ of respondence affirmation of the use of open competitive bidding which represents fairness, accountability, and openness. It is therefore recommended that there should be a strong understanding between the stakeholders in the construction industry to increase the compliance rate of the PPA (2007) to reduce the project cost overrun and time overrun. The limitation of this study is that it covers only north-central universities in Nigeria. Further research should be carried out in other geo-political zones and establishments for generalization.

The procurement act is not peculiar to Nigeria because its purpose is to maximize the economy and ensure efficiency in the procurement of goods and services. The main focus of the paper is to ensure international best practices and value for money that will enable other countries to carry out business in the Nigerian construction industry successfully. This is per the World Bank agenda for developing countries which led to the enactment of the procurement act of 2007 in Nigeria.

\section{References}

Adusei, C. and Dadson, A. (2015). Implementation challenges of the public procurement act by selected metropolitan, municipal and district assemblies in the Ashanti region, Ghana. iBusiness, 7(1), 39-50. DOI: 10.4236/ib.2015.71005.

Ali, N. I. (2020). Can Public Procurement bring SocioEconomic Empowerment? Retrieved from www.blogs.worldbank.org/can-public-procurementbring-socio-economic-empowerment? on May 15, 2021.

Ayangade, J. A., Wahab, A. B., and Alake, O. (2009). An investigation of the performance of due process mechanism in the execution of construction projects in Nigeria. The Journal of Civic Engineering Science and Application, 11(1), 1-7.

Bodunrin, O. (2016). The Impact of Fiscal and Monetary Policy on Nigerian Economic Growth. Munich Personal RePEc Archive. University of East Anglia. DOI: 10.13140/RG.2.2.29718.40005.

BMPIU. (2007). The ABC of the Contract Due Process Policy. A Manual on Public Procurement Reform Programme in Nigeria, State House, Abuja, Nigeria. CIBA Malaysia (2013a) Edition.

Bosio, E. and Djankov, S. (2020). How Large is Procurement? Retrieved from www.blogs.worldbank.org/how-large-is-procurement? on May 8, 2021.

Cherry, K. (2021). What is Compliance? Retrieved from www.verywellmind.com/what-is-compliance? On April 18, 2021.

Crawshaw, G. (2017). The Top Six Challenges Facing Procurement. Retrieved from www.cips.org on June 10, 2021.

Egan, J. (1998). Rethinking Construction -The Report of The Construction Task Force. Department of Environment, Transport \& The Regions, London.

Ekwekwuo, C. C. (2016). A case study of the Nigerian procurement monitoring program and its portal and observatory. Wyith Limited and Wyith Institute, 1-5. Retrieved from http://www.commentary.com/procurement monitorin g.htm

Enofe, A. O., Okuonghae, O., and Sunday, O. I. (2015). The impact of public procurement act on government 
accountability in Nigeria. Journal of Political Science and Leadership Research, 1(8), 114-128.

Eze, N. M. (2015). Due process in the procurement system: the Nigeria experience. International Journal of Engineering Sciences \& Research Technology, 9655(7), 234-243.

Ezekwezilli, O. (2004). Understanding due process. Villascope. 4, (2) April.

Familoye, O. (2012). Public sector clients in Nigeria appraisal of the application of the public procurement act 2007. A thesis submitted for the award of M.Tech in Quantity Surveying, Federal University of Technology Akure, Nigeria.

Familoye, O., Ogunsemi, D. R., and Awodele, O. A. (2015). A Comparative Analysis of Nigeria Public Procurement Act 2007 with Selected International Procurement Acts. Paper presented at the Environmental Design and Management International Conference on Responsive Built Environment held at Faculty of Environmental Design and Management, Obafemi Awolowo University, Ile Ife, Nigeria, 9-12 March, 2015. pp 173-182.

Familoye, O., Ogunsemi, D. R., and Awodele, O. A. (2015). Assessment of the challenges facing the effective operations of the Nigeria public procurement act 2007. International Journal of Economics, Commerce and Management, 3(11), 957-968.

Hui, W., Othman, R., Normah, O., Rahman, R., and Haron, N. (2011). Procurement issues in Malaysia. International Journal Public Sector Manage, 24(6), 567-593.

Ibrahim, K., and Mbamali, I. (2013). Availability of housing financing funds for private estate developers in Abuja, Nigeria. Proceeding of Sustainable Building Conference, Abuja Nigeria, 25 July, 2013.

Jacob, O. A. (2010). Procurement law in Nigeria: Challenge for attainment of its objectives. Retrieved from:

http://www.pulp.up.ac.za/pdf/2011_02/2011_02_j_ch apter6.pdf

Jibrin, M. S., Ejura, S. B., and Augustine, N. I. (2014). The public procurement reforms in Nigeria: Implementation and compliance challenges. Journal of Asian Business Strategy, 4(11), 149-162.

Krivish, A. and Krekele, I (2013). Challenges of Public Procurement in Projects with Multifunding in Project Management Development - Practice and Perspectives, $2^{\text {nd }}$ International Scientific Conference on Project Management in the Baltic Countries, Riga, University of Latvia,

Lex Mundi Ltd (2012). Public Procurement. A Publication of Udo Udoma \& Belo-Osage published by Lex Mundi Publications, Lagos, Nigeria.

Muhammad, B. A., Adamu, T., and Ladi B. D. (2015). Appraisal of construction project procurement policies in Nigeria. American Journal of Engineering Research, 4(3), 19-24

Nwafor, F. C. (2013). The FOIA and public procurement: Enhancing accountability and public participation in Nigeria. Public Policy and Administration Research, 3 (12), 140-145.

Obanikoro, M. (2013). Lekki-Epe Expressway concession buy back, a badly put together cover-up. Retrieved from www.theeagleonline.com.ng/lekki-epeexpressway-concession-right-buy-back on May 18, 2014.
Ogunsanmi, O. E. (2013). Effects of procurement-related factors on construction project performance in Nigeria. Ethiopian Journal of Environmental Studies and Management, 6(2), 215-222.

Ojo, A. E. and Gbadebo, A. M. (2014). An assessment of non-compliance with procurement proceedings in procurement of works in Nigeria. International Journal of Economic and Business Management, 2(3), 25-34.

Osei-Tutu, E., Badu, E., and Owusu-Manu, D. (2010). Exploring corruption practices in public procurement of infrastructural projects in Ghana. International Journal of Managing Projects in Business, 3, 236-256. DOI: $10.1108 / 17538371011036563$.

Osei-Tutu, E., Sarfo, M., and Ameyaw, C. (2011). The level of compliance with the Public Procurement Act (Act 663) in Ghana. Managenment and Innovation for a Sustainable Built Environment. ISBN: 9789052693958.

Oyedele, O. (2016). Assessment of causes of building collapse in Nigeria. Unpublished project work of the construction industry and the economy.

Parra, J. D. A. (2021). Public Procurement. Retrieved from https://jusmundi.com/en/document/wiki/en-publicprocurement on June 15, 2021.

PPA (2007). Public Procurement Act 2007, Federal Republic of Nigeria. Retrieved from www.bpp.org.ng on October 13 $3^{\text {rd }}, 2014$.

Reading Report (1995). Trusting The Team, The Best Practice Guide to Partnering in Construction. Centre for Strategic Studies in Construction. University of Reading, UK.

Transparency International. (2012). Ghana Corruption Perception Index. Retrieved from http://disqus.com/forums/transparencyinternational/htt pwwwtransparencyorgcountrygha/trackback/ on December 25, 2021.

Trochim, W. M. K. (2002). General Issues in Scaling In: Odeyinka, H. A. (2003) The Development and Validation of Models for Assessing Risk Impacts on Construction Cashflow Forecast. Unpublished Ph.D. Thesis Glasgow Caledonian University, Glasgow, Scotland, United Kingdom.

Williams-Elegbe, S. (2015). A comparative analysis of Nigerian public procurement act against international best practice. Journal of African Law, 59(1), 85 - 98.

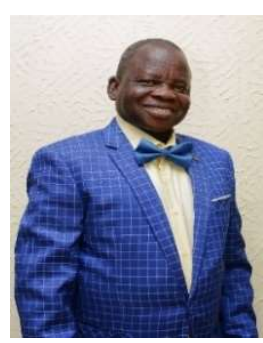

Dr. Olusola Festus Akinradewo is a Senior Lecturer in the Department of Quantity Surveying, The Federal of Technology, Akure, Nigeria. He is a Fellow of the Nigerian Institute of Quantity Surveyors and a member of the Society of Construction Industry Arbitrators of Nigeria. His research interest is Cost and Contract Management. He loves reading about sports and traveling.

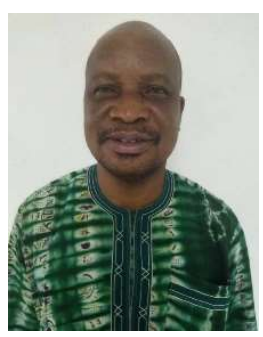

Mr. Omojola Anthony Bamidele is Deputy Director of Physical Planning and Development in the National University Commission, Abuja, Nigeria. He is an M.Tech. graduate of Quantity Surveying from The University of Technology, Akure, Nigeria. He is a member of the Nigerian Institute of Quantity Surveyors. He is an Administrator per Excellency. 
136 Akinradewo, O. F., Bamidele, O. A., and Ogunsemi, D. R.

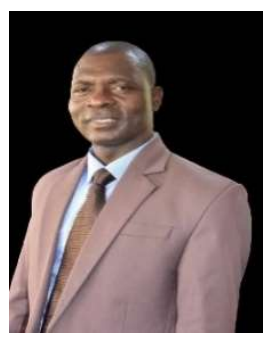

Professor Deji Rufus Ogunsemi is a Professor in the Department of Quantity Surveying at the Federal University of Technology, Akure, Nigeria. His areas of specialization are Cost Management, Procurement Studies, Housing Studies and Project Management. He is a fellow of the Nigerian Institute of Quantity Surveyors and a Fellow of the Nigerian Institute of Building. He has been a lecturer for over 30 years. 